\title{
Effects of withholding food for 0-72 h on mating, pregnancy rate and pituitary function in female rats
}

\author{
T. J. McClure* and J. Saunders \\ AFRC Institute of Animal Physiology, Babraham, Cambridge CB2 4AT, U.K.
}

\begin{abstract}
Summary. Food was withheld from female rats for $0-72 \mathrm{~h}$ at various stages of the oestrous cycle. Withholding food for periods of $24 \mathrm{~h}$ ending at $12: 00 \mathrm{~h}$ on the day of prooestrus reduced the mating rate from 61 to $25 \%(P<0.05)$ but not the pregnancy rate of those rats that mated. Fasting for $24 \mathrm{~h}$ ending at $18: 00 \mathrm{~h}$ on the day of pro-oestrus reduced the pregnancy rate from 82 to $18 \%(P<0.05)$ without affecting the mating rate and a $48-\mathrm{h}$ fast starting at $12: 00 \mathrm{~h}$ on the day of pro-oestrus reduced the pregnancy rate from 82 to $25 \%(P<0.05)$. Withholding food for $23 \mathrm{~h}$ ending at $17: 00 \mathrm{~h}$ on the day of pro-oestrus prevented the LH and prolactin surges normally present at 17:00 h on this day. The treatments had no apparent effect on the ability of the adenohypophysis to release $\mathrm{LH}$ in response to injections of $\mathrm{GnRH}$. When ovariectomized female rats fasted for 0-72 $\mathrm{h}$ and given 2 injections of oestradiol dibenzoate to test the ability of the hypothalamus to respond to an increasing plasma oestradiol concentration by stimulating the release of $\mathrm{LH}$, a fast for $24 \mathrm{~h}$ reduced and a fast for $72 \mathrm{~h}$ completely prevented LH release.
\end{abstract}

\section{Introduction}

Restricting the quantity of food fed to rats and withholding all food from mice for short periods renders them infertile (Marrian \& Parkes, 1929; McClure, 1961, 1966). This effect is known to be mediated mainly through the anterior pituitary gland (Pomerantz \& Mulinos, 1939; McClure, 1967), probably by preventing the release of gonadotrophins. Except during short-term fasting when the primary biochemical change is hypoglycaemia (McClure, 1967), the chain of reactions between the dietary deficiency and pituitary gonadotrophic failure is not understood.

This paper reports the results of experiments on the effects of depriving rats of all food for $0-72 \mathrm{~h}$ at various stages of the reproductive cycle.

\section{Materials and Methods}

Preliminary trials indicated that female rats were less fertile when fasted for $\geqslant 24 \mathrm{~h}$ during late dioestrus and early pro-oestrus, for $\geqslant 48 \mathrm{~h}$ from pro-oestrus and for $72 \mathrm{~h}$ starting at any stage of the cycle. Four experiments were then designed to determine the effect, (1) of minimal periods of fasting on mating, pregnancy and fertility rates; (2) of fasting on plasma reproductive hormone concentrations; (3) on the sensitivity of the adenohypophysis to GnRH; and (4) on the sensitivity of the hypothalamus to oestradiol.

* Present address: Department of Veterinary Clinical Studies, University of Sydney, New South Wales 2006, Australia. 


\section{Experiment 1: effect on mating, pregnancy and fertility rates}

Adult female Wistar rats weighing $200-250 \mathrm{~g}$ were kept at $22^{\circ} \mathrm{C}$ with a 12 -h $(06: 00-18: 00 \mathrm{~h})$ light, 12-h dark photoperiod. Vaginal smears were taken daily at $09: 00 \mathrm{~h}$ to determine the stage of the oestrous cycle, and after 2 normal 4-day cycles, the rats were deprived of all food, but not water, for 0 or $24 \mathrm{~h}$ starting at $12: 00$ or $18: 00 \mathrm{~h}$ on the day of dioestrus, or for $48 \mathrm{~h}$ starting at 12:00 h on the day of pro-oestrus (Groups 1-4 respectively, Table 1). Adult male rats were placed in cages with the females on the day of this dioestrus. Vaginal smears were taken daily to check on the cycles and for evidence of mating as indicated by the presence of spermatozoa in the smears. The rats were killed 8 days after the next oestrus whether or not spermatozoa were found in the vaginal smears and examined for pregnancy. The 'mating rate' was determined by the number of rats mated/number of rats placed with male rats; the 'pregnancy rate' by the proportion of mated rats that were pregnant when examined and the 'fertility rate' by the number of rats pregnant/number placed with male rats. Fisher's exact probability tests were used to determine the significance of differences in rates.

\section{Experiment 2: effect on plasma reproductive hormone concentrations}

After 2 normal cycles, rats, as described in Exp. 1, were fasted for 0-72 h starting at 12:00 h on the day of the next oestrus, metoestrus, dioestrus or pro-oestrus or at 18:00 h on the day of dioestrus (Groups 1-6, Table 2). Blood samples were taken when possible from 6 rats per group at $01: 00 \mathrm{~h}$ on the day of the first dioestrus after fasting started when peak progesterone concentrations were expected; at $09: 00 \mathrm{~h}$ (peak oestradiol) and at 17:00 h (peak prolactin and $\mathrm{LH}$ ) on the day of prooestrus; at 18:00 h at oestrus (peak prolactin); and at 04:00 h on the day of the next dioestrus (peak progesterone concentrations) (Smith, Freeman \& Neill, 1975). The rats that had not been sampled by the end of $72 \mathrm{~h}$ without food were then re-fed. The samples were collected in heparinized syringes from the caudal vena cava under pentobarbitone sodium anaesthesia, centrifuged and the plasma stored at $-20^{\circ} \mathrm{C}$ until analysis for oestradiol-17 $, \mathrm{FSH}, \mathrm{LH}$, prolactin and progesterone. The concentrations of LH, FSH and prolactin were measured with a specific radioimmunoassay, supplied as kits by Dr A. F. Parlow under the NIAMDD rat Pituitary Hormone Distribution Program. The results $(\mathrm{ng} / \mathrm{ml})$ are expressed in terms of the LH-RP-1, FSH-RP-1 and Prl-RP-2 standards. Intra-assay coefficients of variation were $6 \cdot 1 \%(n=4), 6 \cdot 2 \%(n=4)$ and $3 \cdot 1 \%(n=4)$ for plasma pools containing 50, 100 and $250 \mathrm{ng} \mathrm{LH} / \mathrm{ml} ; 6 \cdot 5 \%(n=4)$ and $5.8 \%(n=4)$ for plasma pools containing 280 and $920 \mathrm{ng} \mathrm{FSH} / \mathrm{ml}$, respectively, and $16 \cdot 1 \%(n=4), 9 \cdot 4 \%(n=4)$ and $6.9 \%(n=4)$ for plasma pools containing $3 \cdot 0,12.5$ and $32.0 \mathrm{ng}$ prolactin $/ \mathrm{ml}$, respectively. All samples were assayed in one batch. The sensitivity, defined as two standard deviations from the counts bound at zero concentration, was 1.6, 24.8 and $0.06 \mathrm{ng} /$ tube for LH, FSH and prolactin, respectively.

Progesterone was measured by the method described by Heap, Gwyn, Laing \& Walters (1973) using antiserum 465 no. 6 (kindly provided by Dr B. J. A. Furr) which was raised in a goat immunized against progesterone conjugated to bovine serum albumin through the 11-position. The cross-reactivities of the antiserum have been reported by Sheldrick, Wright, Allen \& Heap (1977). The sensitivity of the assay was $22.3 \mathrm{pg} /$ tube, recovery of labelled tracer from plasma was $92.8 \% \pm$ $2 \cdot 8(n=13)$, and the intra-assay variation $6.2 \%(n=2)$ and $3.8 \%(n=2)$ for plasma pools of 50 and $200 \mathrm{pg}$ progesterone/tube; the inter-assay variation was $14.5 \%(n=13)$ and $14.2 \%(n=13)$ respectively.

Oestrogens were measured by the method described by Challis, Heap \& Illingworth (1971) using antiserum 461 no. 6 (kindly provided by Dr B. J. A. Furr) which was raised in a goat immunized against oestradiol-17 $\beta, 17$-hemisuccinyl-bovine serum albumin. The cross-reactivities have been reported by Heap \& Hamon (1979). The sensitivity of the assay was $3 \cdot 1 \mathrm{pg} /$ tube $(n=13)$, and the recovery of labelled tracer from plasma was $87.0 \% \pm 1 \cdot 3(n=16)$. The intra-assay variation was $5.8 \%(n=2)$ and $5.3(n=2)$ for plasma pools of 50 and $100 \mathrm{pg} /$ tube and the inter-assay variation was $13.7 \%(n=16)$ and $13 \cdot 2 \%(n=16)$ respectively.

Insufficient plasma was obtained to complete all the prolactin determinations. The significance of differences in hormone concentrations was determined by Student's test (unpaired) 23 11:31:35AM 
Experiment 3: effect of withholding food on the sensitivity of the adenohypophysis to GnRH

Food was withheld from 56 4-day-cyclic female rats as described in Exp. 1 for 72, 48, 24 or $0 \mathrm{~h}$ from $13: 30 \mathrm{~h}$ on the days of pro-oestrus, oestrus, metoestrus and dioestrus respectively. At $13: 30 \mathrm{~h}$ on the day of the dioestrus at the end of the fast the rats were anaesthetized with pentobarbitone sodium, blood samples were taken by cardiac puncture and the animals were injected i.v. with GnRH (Luteinizing Hormone Releasing Hormone (LRH, porcine), Beckman, Palo Alto, California) at the rate of $50 \mathrm{ng} / 100 \mathrm{~g}$ liveweight, and injected again with the same dose at $14: 30 \mathrm{~h}$, $1 \mathrm{~h}$ later, using the technique described by Aiyer, Chiappa \& Fink (1974). At 14:50 h, the rats were exsanguinated from the aorta whilst still anaesthetized, the samples were heparinized and centrifuged and the plasma stored at $-20^{\circ} \mathrm{C}$ until analysis for LH (as described for Exp. 2).

\section{Experiment 4: effect of withholding food on the positive steroid feedback mechanism}

Adult female rats similar to those in Exp. 1 which had been ovariectomized 5-6 weeks previously were injected i.m. with $20 \mu \mathrm{g}$ oestradiol dibenzoate in alcohol/vegetable oil at 12:00 h and again $72 \mathrm{~h}$ later with a second dose of $20 \mu \mathrm{g}$ or $4 \mu \mathrm{g}$ oestradiol dibenzoate ("positive steroid feedback test') (Caligaris, Astrada \& Taleisnik, 1968; Brown-Grant, 1974). The 40 rats, allocated to 4 groups, were fasted for $0,24,48$ or $72 \mathrm{~h}$ ending at $12: 00 \mathrm{~h}$ on the day they were given their $2 \mathrm{nd}$ injection of oestradiol dibenzoate. Samples of blood were taken by cardiac puncture under ether anaesthesia just before the $2 \mathrm{nd}$ dose of oestradiol was given and $6 \mathrm{~h}$ later $(18: 00 \mathrm{~h})$ from the aorta under pentobarbitone sodium anaesthesia. The samples were treated and analysed for $\mathrm{LH}$ as described for Exp. 2.

\section{Results}

\section{Experiment 1}

As shown in Table 1, fasting for $24 \mathrm{~h}$ from 12:00 h on the day of dioestrus to $12: 00 \mathrm{~h}$ on the day of pro-oestrus reduced the percentage of rats that were mated $(P<0.05)$, but had no effect upon the

Table 1. Mating rates, pregnancy rates and fertility of female rats deprived of all food, but not water, for 0,24 or $48 \mathrm{~h}$ at different stages of the oestrous cycle

\begin{tabular}{|c|c|c|c|c|}
\hline Group & Fast & $\begin{array}{l}\text { Mating } \\
\text { rate }\end{array}$ & $\begin{array}{l}\text { Pregnancy } \\
\text { rate }\end{array}$ & $\begin{array}{l}\text { Fertility } \\
\text { rate }\end{array}$ \\
\hline 1 & $0 \mathrm{~h}$ (control) & $17 / 28(61 \%)$ & $14 / 17(82 \%)$ & $14 / 28(50 \%)$ \\
\hline 2 & $\begin{array}{l}24 \mathrm{~h} \text { ending at } \\
12: 00 \mathrm{~h} \text { on the day } \\
\text { of pro-oestrus } \\
\text { (dioestrus-pro- } \\
\text { oestrus) }\end{array}$ & $* 6 / 24(25 \%)$ & $4 / 6 \quad(67 \%)$ & $* 4 / 24(17 \%)$ \\
\hline 3 & $\begin{array}{l}24 \mathrm{~h} \text { ending at } \\
18: 00 \mathrm{~h} \text { on the day } \\
\text { of pro-oestrus } \\
\text { (dioestrus-pro- } \\
\text { oestrus) }\end{array}$ & $11 / 17(65 \%)$ & $\uparrow 2 / 11(18 \%)$ & ${ }^{*} 2 / 17(12 \%)$ \\
\hline 4 & $\begin{array}{l}48 \mathrm{~h} \text { starting at } \\
12: 00 \mathrm{~h} \text { on the day } \\
\text { of pro-oestrus } \\
\text { (pro-oestrus-met- } \\
\text { oestrus) }\end{array}$ & $8 / 9 \quad(89 \%)$ & $* 2 / 8 \quad(25 \%)$ & $2 / 9 \quad(22 \%)$ \\
\hline
\end{tabular}

* Significantly different from Group 1 value, $P<0.05$.

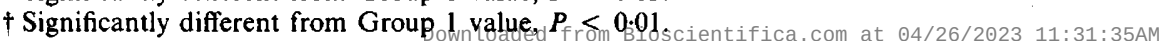




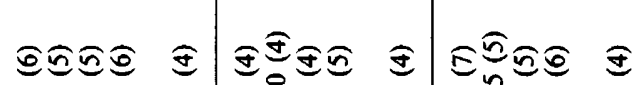

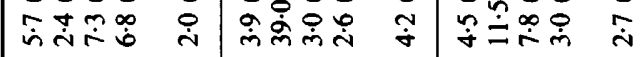
$+1+1+1+1+1 \quad+1+1+1+1+1+1+1+1+1+1$

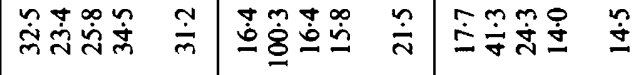

ส

这

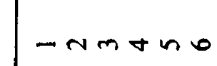


pregnancy rate of those rats that mated. Delaying the fast for $6 \mathrm{~h}$ did not affect the mating rate but significantly reduced the percentage of mated rats that were pregnant when killed 8 days later $(P<$ $0 \cdot 01)$. Although without effect on the mating rate, withholding all food for $48 \mathrm{~h}$ from 12:00 $\mathrm{h}$ on the day of pro-oestrus significantly reduced the pregnancy rate $(P<0.05)$.

\section{Experiment 2}

No significant changes $(P<0.05)$ were found in plasma FSH concentrations. The plasma oestradiol-17 $\beta$, LH and progesterone concentrations of the rats are shown in Table 2. Significant reductions in plasma oestradiol-17 $\beta$ occurred on the day of pro-oestrus in rats which had been without food for 69-72 h (Group 2) when compared with the fully fed controls (Group 1) from a mean of $56.4 \pm 5.1$ to $37.2 \pm 4.0 \mathrm{pg} / \mathrm{ml}(P<0.01$, Table 2$)$, but not in the rats fasted for $45-53 \mathrm{~h}$ (Group 3). The plasma LH concentration was significantly depressed in the samples taken at 17:00 h on the day of pro-oestrus in rats fasted for $\geqslant 23 \mathrm{~h}$ (Group 5) $(P<0.05$, Table 2). Significant reductions in plasma progesterone concentrations were also found at $04: 00 \mathrm{~h}$ on the day of the $2 \mathrm{nd}$ dioestrus in rats fasted for $72 \mathrm{~h}$ (Group 3) $(P<0.05$, Table 2).

Sufficient plasma was obtained to compare the prolactin values on the day of pro-oestrus $(09: 00$ and 17:00 h) for the rats fasted for $45-72 \mathrm{~h}$ with the fully fed control rats. The mean \pm s.e.m. plasma concentrations for the groups were $5 \cdot 5 \pm 2 \cdot 28 \mathrm{ng} / \mathrm{ml}(n=8)$ and $58.0 \pm 7 \cdot 18 \mathrm{ng} / \mathrm{ml}(n=6)$ respectively $(\mathrm{t}=2.45, P<0.05)$.

\section{Experiment 3}

The mean plasma LH concentrations of the dioestrous rats held without food for $0-72 \mathrm{~h}$ just before receiving the $1 \mathrm{st}$, and $20 \mathrm{~min}$ after the $2 \mathrm{nd}$, dose of LHRH are shown in Table 3 . Fasting for up to $72 \mathrm{~h}$ had no apparent effect on the plasma LH concentration after the 2 nd dose of LHRH.

Table 3. Plasma LH concentrations in female rats, deprived of all food for $0-72$ $\mathrm{h}$, just before the 1 st and $20 \mathrm{~min}$ after a second injection of $\mathrm{GnRH} 1 \mathrm{~h}$ later

\begin{tabular}{ccc}
\hline $\begin{array}{c}\text { Period } \\
\text { during which } \\
\text { food withheld } \\
\text { (h) }\end{array}$ & \multicolumn{2}{c}{ Plasma LH conc. (ng/ml) } \\
\cline { 2 - 3 } & Before 1st injection & 20 min after 2nd injection \\
\hline 0 & $13.9 \pm 3.5(12)$ & $62.8 \pm 8.2(14)$ \\
24 & $11.9 \pm 2.6(9)$ & $63.5 \pm 8.2(14)$ \\
48 & $15.4 \pm 4.5(13)$ & $52.3 \pm 8.7(14)$ \\
72 & $0 \pm 0(4)$ & $58.2 \pm 14.4(8)$ \\
\hline
\end{tabular}

Values are mean \pm s.e.m. for the number of rats in parentheses.

\section{Experiment 4}

The mean plasma LH concentrations of the ovariectomized rats held without food for $0-72 \mathrm{~h}$ immediately before and $6 \mathrm{~h}$ after the second injection of oestradiol dibenzoate, and the changes in concentations are shown in Table 4 . The 2 nd dose of oestradiol caused significant increases in the plasma LH concentration of the unfasted control rats at both dose rates. Fasting decreased these responses. The increase in plasma $\mathrm{LH}$ concentration after the injection of $4 \mu \mathrm{g}$ oestradiol was reduced by $32 \%$ with $24 \mathrm{~h}$ fasting, $36 \%$ with $48 \mathrm{~h}$ and $100 \%$ with $72 \mathrm{~h}$. The response to the larger $(20$ $\mu \mathrm{g}$ ) dose of oestradiol was not reduced by $24 \mathrm{~h}$ without food. 
Table 4. Plasma LH concentrations (mean \pm s.e.m., $n=5$ ) in ovariectomized rats, deprived of all food for $0-72 \mathrm{~h}$, just before and $6 \mathrm{~h}$ after a second injection of oestradiol dibenzoate

\begin{tabular}{|c|c|c|c|c|}
\hline \multirow{2}{*}{$\begin{array}{l}\text { Period } \\
\text { during which } \\
\text { food } \\
\text { withheld } \\
\text { (h) }\end{array}$} & \multirow{2}{*}{$\begin{array}{l}\text { Dose of } \\
\text { oestradiol } \\
\text { at } 2 \mathrm{nd} \\
\text { injection } \\
(\mu \mathrm{g})\end{array}$} & \multicolumn{3}{|c|}{ Plasma LH conc. (ng/ml) } \\
\hline & & $\begin{array}{l}\text { Before } \\
\text { 2nd } \\
\text { injection }\end{array}$ & $\begin{array}{c}6 \mathrm{~h} \text { after } \\
\text { 2nd injection }\end{array}$ & Difference \\
\hline 0 & $\begin{array}{r}20 \\
4\end{array}$ & $\begin{array}{l}57.6 \pm 7.4 \\
61.2 \pm 8.3\end{array}$ & $\begin{array}{l}169 \cdot 5 \pm 30 \cdot 4^{* *} \\
166 \cdot 1 \pm 22 \cdot 3^{* *}\end{array}$ & $\begin{array}{l}111 \cdot 9 \pm 26 \cdot 5 \\
104.9 \pm 27 \cdot 3\end{array}$ \\
\hline 24 & $\begin{array}{r}20 \\
4\end{array}$ & $\begin{array}{l}61.9 \pm 3.5 \\
68.7 \pm 7.8\end{array}$ & $\begin{array}{l}183 \cdot 0 \pm 31 \cdot 9^{* *} \\
139 \cdot 8 \pm 25 \cdot 2^{*}\end{array}$ & $\begin{array}{r}121 \cdot 0 \pm 33 \cdot 3 \\
71 \cdot 1 \pm 28 \cdot 0\end{array}$ \\
\hline 48 & $\begin{array}{r}20 \\
4\end{array}$ & $\begin{array}{l}75.6 \pm 10.6 \\
86.3 \pm 11.6\end{array}$ & $\begin{array}{l}172.0 \pm 36.6^{*} \\
153.7 \pm 41 \cdot 1\end{array}$ & $\begin{array}{l}96 \cdot 4 \pm 39 \cdot 7 \\
67 \cdot 4 \pm 38 \cdot 8\end{array}$ \\
\hline 72 & $\begin{array}{r}20 \\
4\end{array}$ & $\begin{array}{l}83.9 \pm 5.4 \\
68.9 \pm 6.0\end{array}$ & $\begin{array}{l}88 \cdot 3 \pm 8 \cdot 0 \\
57 \cdot 2 \pm 4 \cdot 2\end{array}$ & $\begin{array}{r}4.4 \pm 10.4 \\
-11.7 \pm 30.1\end{array}$ \\
\hline
\end{tabular}

Significantly different from LH conc. before the 2 nd injection: ${ }^{*} P<0.05,{ }^{* *} P<0.01$.

\section{Discussion}

Withholding food for $24 \mathrm{~h}$ during dioestrus and pro-oestrus reduced the fertility rate from $50 \%$ to $17 \%$ or $12 \%$ according to whether the fast ended at $12: 00 \mathrm{~h}$ or $18: 00 \mathrm{~h}$ on the day of pro-oestrus (Table 1). The timing of the fast influenced the nature of the reproductive failure and may help in understanding the mechanisms involved.

Depriving the rats of all food for $24 \mathrm{~h}$ up to $12: 00 \mathrm{~h}$ on the day of pro-oestrus reduced the mating rate and therefore presumably oestrus, but did not affect the fertility of the few rats which mated. It is reasonable to expect that the later stages of fasting exert a greater effect on reproductive function than the earlier stages. Unpublished data (T. J. McClure) and those of Ellington (1980) indicate that the blood-glucose concentration, which has been shown to be the critical nutrient involved in infertile fasted mice (McClure, 1967), falls in rats to about 66-75\% normal values after $12 \mathrm{~h}$ without food. Examination of published data on blood reproductive hormone levels during the morning of pro-oestrus, when the rats would be hypoglycaemic, shows that the only major change is the rapid increase in oestradiol concentration (Smith et al., 1975). The data in Table 2 (Group 4) suggest that fasting over the 24-h period ending at $12: 00 \mathrm{~h}$ on the day of pro-oestrus would not have affected the plasma oestradiol concentration. Failure to exhibit oestrous behaviour, as deduced by the failure to find spermatozoa or copulation plugs in the vagina, therefore must have resulted from the failure of the higher centres to respond to an increasing oestradiol concentration, either directly or indirectly. A period of $24 \mathrm{~h}$ without food ending at $18: 00 \mathrm{~h}$ on the day of pro-oestrus did not affect the mating rate. A substantial part of the rise in plasma oestradiol has normally occurred by $06: 00 \mathrm{~h}$ on the morning of pro-oestrus, when the plasma glucose concentration would have fallen appreciably. It seems probable then that the signals causing behavioural oestrus are associated with the initial rise in plasma oestradiol concentration during the night of dioestrus leading to pro-oestrus. The fact that overt oestrus does not occur until the next night, when the plasma oestradiol concentration has fallen to a low level, suggests an indirect effect of oestrogen on higher centres rather than a direct one.

Although a fast for $24 \mathrm{~h}$ ending at 18:00 h on the day of pro-oestrus did not affect the mating rate it significantly reduced the pregnancy rate. Smith et al. (1975) have reported that plasma FSH, $\mathrm{LH}$, prolactin and progesterone concentrations increase markedly between 12:00 and 18:00 $\mathrm{h}$ on the afternoon of pro-oestrus (Smith et al., 1975). In Exp. 2 in this study, withholding food significantly reduced the concentration of oestradiol, $\mathrm{LH}$, prolactin and progesterone but after different durations. LH concentration appeared to be the most sensitive, since a fast of $23 \mathrm{~h}$ ending 
at 17:00 $\mathrm{h}$ on the afternoon of pro-oestrus appeared to suppress the LH surge that normally occurs at this time (Table 2; Group 5) and a fast of $72 \mathrm{~h}$ ending at $12: 00 \mathrm{~h}$ on the afternoon of pro-oestrus seemed to have delayed the LH surge by $24 \mathrm{~h}$. The shortest period of fasting, $23 \mathrm{~h}$ ending at $17: 00 \mathrm{~h}$, although apparently suppressing the LH surge, had no effect on oestradiol (Table 2; Group 5), which is responsible for the release of GnRH and consequently LH. It seems likely that the hypothalamus may have failed to respond to the rising oestradiol concentration by not releasing GnRH as normal (Goodman, 1978).

The limited evidence suggests that there may also have been some interference in release of prolactin. If this can be confirmed it may indicate reasons for the effect on fertility of the 48-h period of fasting beginning at 12:00 $\mathrm{h}$ on the day of pro-oestrus.

The significance of the lowered levels of oestradiol and progesterone are more difficult to interpret. Clearly, longer periods without food were necessary before the ovarian steroid hormone concentrations in the blood were affected $(>69 \mathrm{~h}$ and $>58 \mathrm{~h}$, Group 2 and Groups 3 and 6, Table 2, respectively). We suggest that the synthesis of ovarian steroids may be impaired in rats fasted for $72 \mathrm{~h}$ and that this may be a point of difference between the reproductive failure in chronically underfed and acutely starved rats. Alternatively, it may simply reflect a lowered gonadotrophin stimulation of the developing follicle.

The administration of two doses each of $50 \mathrm{ng} \mathrm{LHRH} / 100 \mathrm{~g}$ liveweight 60 -min apart caused a 4.5-fold rise in plasma $\mathrm{LH}$ concentration in the fully fed dioestrous rats, an increase which is consistent with that found by Aiyer et al. (1974). Withholding food for up to $72 \mathrm{~h}$ did not affect the response (Table 3). This evidence from rats deprived of food for short periods is in agreement with that derived from rats underfed for longer periods (Howland, 1976).

If it is assumed that the ovariectomized rats were otherwise similar to intact rats, the evidence from the positive steroid feedback test of hypothalamic GnRH function (Exp. 4, Table 4) indicates that after $24 \mathrm{~h}$ the hypothalamus is beginning to fail to respond to increasing plasma oestradiol levels which normally occur at late dioestrus or early pro-oestrus and that after $72 \mathrm{~h}$ failure is complete. Goodman (1978) showed that the preoptic area of the hypothalamus appears to be the primary site of the positive feedback actions of oestradiol in the rat, triggering the release of GnRH. It seems likely that the blood glucose concentration of the fasted rats is too low to provide the energy for the metabolism of the preoptic and possibly other areas of the hypothalamus, which in turn fail to respond to the increasing oestradiol concentration early in pro-oestrus by triggering the release of GnRH.

\section{References}

Aiyer, M.S., Chiappa, S.A. \& Fink, G. (1974) A primary effect of luteinizing hormone releasing factor on the anterior pituitary gland in the female rat. $J$. Endocr. 62, 573-588.

Brown-Grant, K. (1974) Steroid hormone administration and gonadotrophin secretion in the gonadectomized rat. J. Endocr. 62, 319-332.

Caligaris, L., Astrada, T.J. \& Taleisnik, S. (1968) Stimulating and inhibiting effects of progesterone on the release of luteinizing hormone. Acta endocr., Copenh. 59, 177-185.

Challis, J.R.G., Heap, R.B. \& Illingworth, D.B. (1971) Concentrations of oestrogen and progesterone in the plasma of non-pregnant, pregnant and lactating guinea-pigs. $J$. Endocr. 51, 333-345.

Ellington, S.K.L. (1980) In-vivo and in-vitro studies on the effects of maternal fasting during embryonic organogenesis in the rat. $J$. Reprod. Fert. 60, 383-388.
Goodman, R.L. (1978) The site of the positive feedback action of estradiol in the rat. Endocrinology 102, 151159.

Heap, R.B. \& Hamon, M. (1979) Oestrone sulphate in milk as an indicator of a viable conceptus in cows. $\mathbf{B r}$. vet. J. 135, 355-363.

Heap, R.B., Gwyn, H., Laing, J.A. \& Walters, D.E. (1973). Pregnancy diagnosis in cows; changes in milk progesterone concentration during the oestrous cycle and pregnancy measured by a rapid radioimmunoassay. J. agric. Sci., Camb. 81, 151-157.

Howland, B.E. (1976) Gonadotrophin release induced by Gn-RH or progesterone in female rats maintained on high or low levels of feed intake. J. Reprod. Fert. 47, 137-139.

Marrian, G.F. \& Parkes, A.S. (1929) The effect of anterior pituitary preparations administered during dietary anoestrus. Proc. $R$. Soc. B 105, 248-258. 
McClure, T.J. (1961) Temporary nutritional stress and infertility in female mice. J. Physiol., Lond. 147, 221225.

McClure, T.J. (1966) Infertility in mice caused by fasting at about the time of mating. I. Mating behaviour and littering rates. J. Reprod. Fert. 12, 243-249.

McClure, T.J. (1967) Infertility in mice caused by fasting at about the time of mating. III. Pathogenesis. $J$. Reprod. Fert. 13, 393-403.

Pomerantz, L. \& Mulinos, M.G. (1939) Pseudo-hypophysectomy produced by inanition. Am. J. Physiol. 126, 601 .
Sheldrick, E.L., Wright, P.J., Allen, W.R. \& Heap, R.B. (1977) Metabolic clearance rate, production rate and source of progesterone in donkeys with fetuses of different genotype. J. Reprod. Fert. 51, 473-476.

Smith, M.S., Freeman, M.E. \& Neill, J.D. (1975) The control of progesterone secretion during the estrus cycle and early pseudo-pregnancy in the rat: prolactin, gonadotropin and steroid levels associated with the rescue of the corpus luteum of pseudopregnancy. Endocrinology 96, 219-226.

Received 22 June 1984 